\title{
Kreativitas dalam Desain Iklan Rokok di Jawa, 1930-1970an ${ }^{1}$
}

\author{
Yuhana Setianingrum
}

Alumnus Jurusan Sejarah Fakultas Ilmu Budaya, Universitas Gadjah Mada

\begin{abstract}
This paper, entitled 'The development of cigarette advertising design in Java in 1930 - 1970s', discusses the transformation of cigarette advertising design. It also discusses the influence of colonial and post-colonial political regimes and the modernization in cigarette advertising visualization between $1930-1970$ s. Research is focused on observation of advertising elements, such as headline, body-copy, illustration, and the art of appearance. These were obtained from the primary sources, such as newspapers, which were published during the period. Secondary sources were also used, for example, relevant books. Based on observation and analysis of cigarette advertisements, it is obvious that the creativity in cigarette advertising design continued to grow, and visual transformation from manual illustration to photo technology occured in the period under study. In addition, there were representations of symbols in cigarette advertising design because of the influence of colonial and post-colonial political regimes and because of the process of modernization.
\end{abstract}

Keywords: cigarette, advertisement, newspaper

\begin{abstract}
Abstrak
Tulisan yang berjudul 'Perkembangan Kreativitas Desain Iklan Rokok di Jawa tahun 1930-1970an' ini membahas perkembangan kreativitas dan transformasi visualisasi desain, pengaruh rezim politik kolonial ke pos-kolonial serta modernisasi dalam visualisasi iklan rokok tahun 1930an hingga 1970an. Penelitian difokuskan pada pengamatan unsur-unsur dalam iklan seperti headline, body-copy, ilustrasi, dan gaya perupaan. Unsur-unsur tersebut didapat dari sumber primer yakni surat kabar yang terbit tahun 1930 sampai 1970an, serta sumber sekunder, referensi berupa buku yang relevan. Berdasarkan pengamatan dan analisis terhadap iklan rokok, ditemukan fakta-fakta: pertama, kreativitas pada iklan rokok terus berkembang, dan terjadi transformasi visualisasi 'wajah' iklan dari ilustrasi gambar manual ke teknologi foto pada tahun 1970an. Kedua, adanya representasi simbol-simbol dalam iklan rokok akibat pengaruh rezim politik kolonial ke postkolonial dan modernisasi.
\end{abstract}

Kata kunci: rokok, iklan, surat kabar.

1 Artikel ini bagian dari skripsi S1 berjudul ‘ Perkembangan Kreativitas Desain Iklan Rokok di Jawa tahun 1930-1970an’, Jurusan Sejarah, Fakultas Ilmu Budaya, Universitas Gadjah Mada (2012). 


\section{Pengantar}

Masyarakat tentu mengenal berbagai macam iklan rokok yang ada di media cetak maupun elektronik sekarang ini. Iklan-iklan tersebut muncul seperti halnya perang produk. Siapa yang tak kenal iklan A Mild Sampoerna dengan kampanye iklan 'Bukan basa basi' nya, Sampoerna Hijau dengan 'Gak ada lo gak rame', 'Talk less do more' dari rokok Class Mild atau iklan LA Lights dengan 'Enjoy aja' yang ditujukan untuk segmen perokok anakanak muda. Tidak kalah dengan iklan lainnya, produk Gudang Garam dengan kampanye iklan 'Pria punya Selera', iklan rokok Dji Sam Soe dengan 'Sejarah cita rasa tinggi' yang ditujukan untuk segmen perokok dewasa, dan masih banyak lagi.

Itu hanya beberapa contoh iklan rokok yang sering kita lihat di televisi maupun media cetak. Gambaran yang sangat menarik mengenai iklan rokok sekarang adalah semakin terbuka dalam perang kreativitas, meskipun iklan rokok sekarang dilarang untuk menampilkan gambar produk rokok itu sendiri. Saat ini iklan rokok mempunyai batasan yang sangat ketat dalam penyajiaannya, karena produk yang diiklankan merupakan produk sensitif dan termasuk iklan 'AKROBAT"1 (Budiman Hakim, 2005: 64).

Selain itu rokok selalu diidentikkan dengan pria, maka sangat unik jika yang menjadi model dalam iklannya adalah justru sosok perempuan. Pada kenyataanya memang pada masa itu banyak iklan rokok menjadikan sosok perempuan sebagai modelnya. Apabila dilihat dari sudut pandang sekarang, penggunaan objek gambar merokok, apalagi perempuan sebagai objeknya dalam iklan rokok adalah sesuatu yang dilarang.

Sebuah gambaran bahwa kreativitas dalam membuat iklan juga menentukan image dari produk yang diiklankan. Seperti pendapat Francis S. King dan Otto Kleppner yang menyatakan bahwa bagian paling penting yang bertanggung jawab terhadap perancangan dan penentuan suatu iklan adalah bagian kreatif.

Perkembangan periklanan di Indonesia sendiri dimulai saat masa pemerintahan Hindia Belanda. Awal penggunaan media periklanan sebagai alat penyampai informasi atau pesanpesan perdagangan, dan pemerintahan di Hindia Belanda dirintis sejak Jan Pieterszoon Coen menjabat sebagai Gubernur Jendral (1619-1629) di Batavia. Sejak awal kemunculan iklan di media cetak baik itu surat kabar di Jawa, iklan menjadi bagian tak terpisahkan dari keduanya. Periklanan dan pers media cetak adalah dwitunggal yang tidak dapat dipisahkan (Bedjo Riyanto, 2000: 75-76).

Perkembangan periklanan pada masa kolonial Belanda tidak terlepas dari pengaruh aliran Art Noveau yang tampak terlihat dari iklan-iklan pada masa itu. Pengaruh gaya perupaan seni ini masuk ke Indonesia pada masa kolonial Belanda di Indonesia. Saat itu perusahaan-perusahan periklanan besar seperti ANETA, mendatangkan para perancang iklan dari negeri Belanda.

Lain halnya dengan perkembangan produk rokok itu sendiri, di Indonesia awal industri hasil tembakau dimulai bersama masuknya kolonial Belanda. Perkembangan industri hasil tembakau di indonesia lebih dikaitkan dengan kebangkitan industri rokok. (Emmanuel Subangun, 1993: 4) Salah satunya adalah rokok kretek. Lahirnya industri rokok kretek di Kudus bahkan di Indonesia pada akhir abad 19 adalah salah satu andil dari seorang penduduk Kudus bernama Haji Jamahri (Amen Budiman, 1987: 105). Industri rokok kretek pun berkembang luas di Jawa dari usaha rumahan hingga berskala perusahaan besar seperi Djarum di Kudus, HM. Sampoerna di Surabaya, Gudang Garam di Kediri dll.

Iklan rokok di media cetak telah ada sejak masa Kolonial Belanda. Iklan-iklan rokok zaman dulu memang berbeda dengan iklan rokok sekarang, baik itu dari segi artistik, maupun segi kreatifnya. Iklan tersebut 
mewakili iklan-iklan rokok pada zamannya terus mengalami perubahan dari waktu ke waktu seiring perkembangan zaman dan arus modernisasi. Namun secara keseluruhan, iklan-iklan rokok tersebut mempunyai tujuan untuk memunculkan brand image dari setiap produk rokok yang diiklankan, dan nantinya iklan-iklan tersebut dapat diterima oleh masyarakat. Lantas seperti apakah perubahan visualisasi desain iklan rokok di Jawa seiring dengan pengaruh modernisasi dan perubahan rezim tahun 1930-1970an?

\section{Perkembangan Iklan Rokok di Jawa pada 1930-1970an}

"Iklan rokok adalah suatu bentuk komunikasi non personal yang isinya menginformasikan dan sekaligus menawarkan suatu produk rokok kepada masyarakat umum melalui media massa dan dikemas sedemikian rupa sehingga menarik calon pembeli sebanyak-banyaknya dan semestinya bersifat informatif dan berdaya persuasif...." (B. Wahyudi Joko Santoso, 2000: 13-14).

Bentuk visual iklan-iklan rokok pada tahun 1930an masih sangat sederhana. Adanya unsur-unsur pada komposisi rancangan layout desain iklan, seperti halnya yang diaplikasikan pada era periklanan modern seperti naskah (Headline, Body-Copy, Harga, identitas, Signature Slogan) dan ilustrasi, menandakan bahwa iklan memang telah berkembang pada saat itu, walaupun dalam bentuknya yang masih sederhana.

Dalam penggunaan kata dalam body copy, seperti pada iklan rokok H.D Mac Gillavry (Medan Doenia, 4 Januari 1930) telah menggunakan cara-cara persuasif dengan kata-kata minimalis "Sabetoelnja tida ada jang melawan!”. Merujuk kalimat tersebut, secara tidak langsung produk berusaha memposisikan diri sebagai yang terbaik. Ini dapat disebut sebagai product/brand positioning. (PPPI, 2005: 43)
Dari segi kreativitas lainnya, iklan rokok telah banyak yang mencantumkan logo produk/merk, walaupun logo terlihat masih sederhana, setidaknya hal ini merupakan strategi perusahaan untuk mengenalkan masyarakat tentang logo sebagai identitas suatu merk rokok tersebut. Kreativitas yang dicapai pada iklan rokok tahun 1930an lainnya ditandai dengan penggunaan ilustrasi yang relevan atau simbolis. Ciri gaya perupaannya yang masih sederhana, didominasi dengan penggambaran ilustrasi secara dua dimensi serta penggunaan tipografi yang sederhana. Beberapa iklan juga menggunakan teknik siluet $^{2}$ dalam ilustrasinya, seperti pada iklan rokok Faroka yang dimuat tahun 1933.

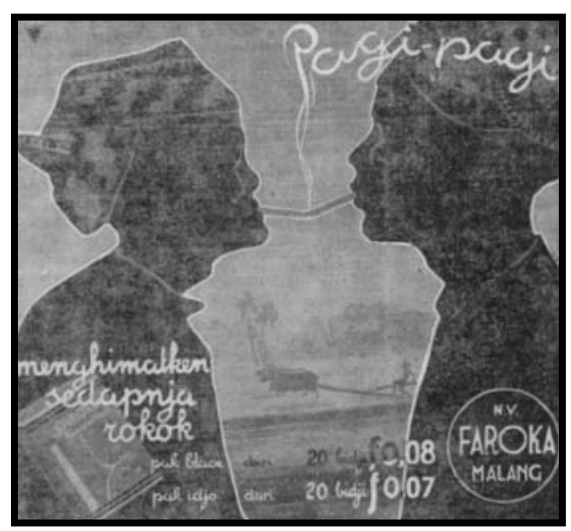

Iklan rokok "Faroka"

Sumber: Sin Po, 6 Mei 1933

Konsep iklan dengan menampilkan ilustrasi produk itu sendiri, menjadi ciri ilustrasi lainnya yang dapat dijumpai pada iklan tahun 1930an. Pemilihan ilustrasi ini merupakan gaya ilustration of the product alone (pembagian ilustrasi menurut Otto Kleppner).

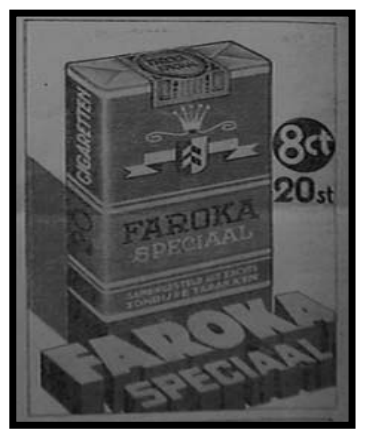

Iklan rokok "Faroka special" Sumber: Sin Tit Po, 26 Januari 1937 
Saat itu, kalimat iklan rokok telah informatif mengenai produk, deskripsi jenis, harga dan macam produk dengan kata-kata yang cukup efektif, persuasif yang ditujukan kepada khalayak. Pemilihan kata yang cukup efektif, efisien, sederhana, dan langsung, sehingga dapat ditangkap langsung oleh khalayak sasaran. Seperti halnya kata "Baroe!" yang merupakan kata klise ${ }^{3}$.

Selain segi kreativitas yang telah dijelaskan di atas, iklan rokok tahun 1930an juga didominasi iklan-iklan dengan unsur-unsur yang sederhana, seperti naskah, ilustrasi, dan tata layout yang seadanya. Iklan-iklan tersebut tetap memberikan pesan informatif kepada khalayak pembaca, meskipun dalam bentuknya yang masih sederhana.

Iklan rokok tahun 1930 juga tidak hanya ditandai dengan model pria sebagai simbol produk rokok, namun juga menggunakan model visualisasi perempuan dalam iklannya. Sisi kreativitas lainnya yang telah ada pada tahun 1930an, yakni bentuk iklan dengan kutipan testimonial ${ }^{4}$. Tahun 1937 jenis ilustration product in setting hadir dalam iklan rokok Majestic (Sin Po, 29 Januari 1937). Visualisasi pada iklan rokok Majectic dalam balutan ilustrasi yang menarik, artistik, realistis, dan modern untuk dilihat dari sudut pandang saat pada masa itu.

Memasuki tahun 1940an dikembangkan berbagai konsep iklan rokok untuk menambah unsur kreativitas, kesan artistik, namun juga sebagai daya tarik iklan. Pada tahun 1941 dimuat iklan rokok Marikangen dengan naskah body copy dibuat Alliteration atau pengulangan kemiripan suara (Frank Jefkins, 1996: 231).

'Pagi Sore Malem

Isep rokok Marikangen,

Pikiran terang tentrem,

Hati girang seneng,

Indonesia poenja bikinan,

Dikerdjakan dengan tangan,

Model lantjip papak pandjang,
Setia laksana kawan,

Diisep rasa mantep,

Seger haroem sedep,

Dipandeng hati greget,

Dibeli, tidak menesel.'

Memasuki era baru, era kemerdekaan, iklan belum banyak berubah dari segi pencapaian kreativitas dan artistiknya. Dimulai dari tahun 1946, kecenderungan iklan rokok kala itu juga banyak didominasi dengan iklan-iklan baris dan kolom.

Memasuki tahun 1950an, perkembangan kreativitas desain iklan rokok di Indonesia cenderung masih stagnan. Memasuki tahun 1950an, sosok perempuan tetap menjadi salah satu daya tarik perancang iklan sebagai model iklan rokok. Selanjutnya pada periode ini, iklan sebagai media informatif untuk menawarkan suatu produk kepada masyarakat ternyata juga mempunyai fungsi lainnya sebagai media untuk menyampaikan ucapan selamat hari raya.

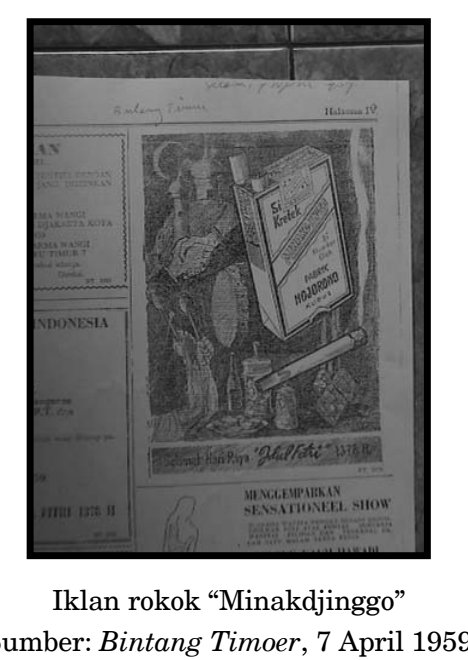

Memasuki tahun 1960an iklan dengan penampilan ilustrasi tunggal produk rokok itu sendiri (ilustrasi of product alone) semakin banyak, namun kreativitas yang dihadirkan pada iklan rokok tersebut cenderung masih biasa. Memasuki tahun 1960an ilustrasi iklan rokok mulai giat dalam tampilannya, dengan karakteristik gaya perupaan realis, nyata dan 
semakin modern, serta pemilihan karakteristik figur pria elegan dan eksklusif. Tampilan desain layout iklan mulai lebih menarik dan modern. Konsep ini terus berkembang, termasuk kreativitas penggunaan bahasa asing sebagai bahasa pengantar iklan, yakni bahasa Inggris. Slogan dibuat dengan kata-kata yang menarik dan relevan dengan target sasaran produk.

Sebuah perubahan besar pada iklan rokok terjadi pada tahun 1970an. Tak dapat dipungkiri bahwa perubahan yang terjadi pada iklan, terutama iklan rokok saat itu tidak dapat dipisahkan dari perkembangan teknologi percetakan dan teknologi pendukung yang semakin mutakhir, sumber daya manusia yang semakin terampil (perancang iklan), industri rokok yang semakin berkembang, dan meningkatnya masyarakat konsumen.

Sebuah gambaran yang jelas perubahan desain iklan rokok terjadi dengan bantuan teknologi dan kreativitas perancang iklan. Salah satu perubahan yang signifikan dan menjadi pembeda yang sangat jelas dibandingkan iklan-iklan sebelumnya adalah penggunaan media foto sebagai ilustrasi pada iklan dan iklan berwarna. Perkembangan ini tentunya merupakan kemajuan dalam pencapaian nilai artistik iklan yang menambah kesan nyata dan menarik perhatian pada iklan.

Selain itu, dalam bukunya, Bedjo Riyanto memaparkan mengenai salah satu perkembangan iklan yang cukup menarik pada masa Kolonial, yakni penggunaan tokoh elite politik (bupati), dan terkenal sebagai maskot penarik perhatian dan merupakan tema sentral iklan. Hal ini dilakukan sebagai strategi pemasaran yang efektif, sehingga mampu menarik perhatian, menciptakan kesan, memberikan pengaruh yang menguntungkan bagi produk yang diiklankan. Konsep dan strategi penjualan seperti itu masih terus berkembang hingga era modern saat ini (Bedjo Riyanto, 2000: 137-139).
Konsep iklan kreatif dan modern yang hampir sama juga dikembangkan oleh iklan Ardath (Kompas, Senin, 2 Mei 1977), yang menampilkan bintang iklan yang sekaligus bintang film terkenal dan sukses pada eranya. Pemilihan bintang film tersebut dianggap mewakili dan menjadi simbol kesuksesan yang menjadi slogan produk rokok tersebut. Penampilan sosok terkenal mampu menarik perhatian dan mempengaruhi masyarakat dengan citra ketenarannya.

Perkembangan iklan yang berhubungan dengan modernisasi teknologi selain penggunaan foto sebagai media untuk menciptakan ilustrasi juga ditandai oleh munculnya iklan cetak berwarna. Tahun 1970an banyak bermunculan iklan yang dicetak berwarna. Walaupun tidak semua menggunakan teknologi cetak warna, namun beberapa iklan, terutama iklan rokok memanfaatkan teknologi cetak warna sebagai bagian kreativitas, artistik, dan juga unsur penarik perhatian.

\section{Pengaruh Perubahan Rezim Politik pada Iklan Rokok}

Perkembangan iklan di Indonesia tak dapat dipisahakan dari elemen-elemen pendukungnya. Iklan merupakan bentuk refleksi perkembangan zaman, refleksi dari kompleksitas situasi masyarakat pada zamannya yang tidak dapat dipisahkan dari konteks perkembangan masyarakat pendukungnya (Bedjo Riyanto, 2000: 74) termasuk bagian dari keberadaan dan kekuasaan rezim politik kala itu. Rezim kekuasaan mampu mempengaruhi iklan-iklan rokok dengan menampilkan simbol visual refleksi perkembangan zaman itu sendiri seperti elemen-elemen kolonial, post-colonial, dan ke-Indonesian yang dihadirkan dalam iklan rokok. 


\section{Elemen-Elemen Kolonial (1930-1945)}

Pada awal abad 16, kedatangan kolonial Belanda membawa pengaruh terhadap perkembangan teknologi percetakan, yang juga memberikan dampak pada munculnya media komunikasi masa, yakni surat kabar pada saat itu. Percetakan dikenal sejak kedatangan Belanda pada masa awal tujuannya dalam perdagangan rempah-rempah. Awal pemanfaatan iklan di Hindia Belanda tidak dapat dilepaskan dari penggunaan teknologi percetakan (PPPI, 2005: 3). Inilah bentuk awal pengaruh Kolonial pada perkembangan iklan di Hindia Belanda kala itu.

Elemen-elemen kolonial lain yang dihadirkan (inclusi) dan menjadi salah satu ciri yang paling menonjol pada iklan-iklan rokok tahun 1930 hingga 1945 adalah penggunaan bahasa Belanda sebagai bahasa pengantar. Penggunaan bahasa Belanda tersebut baik secara keseluruhan maupun dipadukan dengan bahasa Indonesia. Penggunaan bahasa Belanda termuat dalam penggunaan istilah-istilahnya. Ini merupakan pengaruh langsung dari rezim politik yang berkuasa pada waktu itu. Elemen tersebut begitu esensial mengingat banyak surat kabar yang menunjang periklanan merupakan milik orang Belanda maupun Eropa. Bahasa Belanda sendiri merupakan bahasa resmi pemerintahan sejak kolonial Belanda menduduki Hindia Belanda (Marwati Djoened Poesponegoro, 1992: 103). Secara tidak langsung penggunaan bahasa Belanda sebagai bahasa pengantar dalam iklan pada masa Kolonial dapat digolongkan sebagai bentuk pengerucutan segmentasi pasar, karena tidak semua masyarakat mampu membaca dan bercakap dalam bahasa Belanda.

Unsur-unsur rezim kolonial lainnya yang dihadirkan dalam iklan rokok dan menarik perhatian secara visual adalah tampilan ilustrasi yang menghadirkan figur tokoh Belanda atau Eropa lainnya. Secara visual, iklan-iklan masa Kolonial masih dipengaruhi oleh "Hollandsch denken en Hollandsch inzicht" (berpikir dan berpandangan ala Belanda) (PPPI, 2005: 88).

Selain menampilkan figur-figur tokoh Barat, visualisasi pengaruh budaya Barat juga terbentuk dengan penghadiran tokohtokoh komik atau kartun Barat, seperti Three Musketeers. Iklan cerutu Drie Musketiers (Sin Po, 24 Juni 1933) yang menghadirkan simbolsimbol budaya Barat melalui visualisasi figur tokoh ksatria Three Musketeers atau Drie Musketeirs dalam bahasa Belanda. Sesuai dengan nama produk, secara kreatif dan adanya relevansi, iklan tersebut juga menampilkan tiga tokoh ksatria Drie Musketiers sebagai ilustrasi.

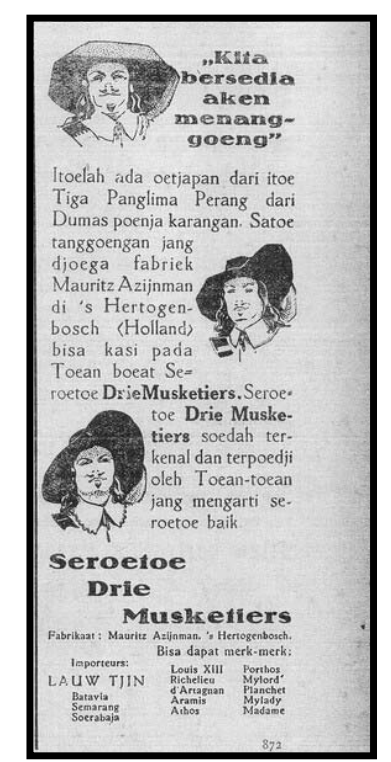

Iklan cerutu "Drie Musketiers" Sumber: Sin Po, 24 Juni 1933

Elemen-elemen lain yang dihadirkan pada masa Kolonial adalah simbol ekonomi, yakni penggunaan mata uang Gulden atau Florin (f.) sebagai alat transaksi ekonomi, alat pembayaran.

\section{Elemen-elemen Pos-kolonial}

Dampak yang ditimbulkan pasca kemerdekaan juga menjadi sebuah refleksi sebuah lahirnya kebebasan menyatakan kemerdekaan, dalam bentuk pesan selamat, menyambut hari kemerdekaan Republik 
Indonesia. Beberapa iklan rokok yang mengangkat tema nasionalisme dalam rangka peringatan HUT RI, antara lain iklan rokok Gudang Garam (Kompas, 18 Agustus 1975). Simbol perjuangan kemerdekaan dihadirkan dalam pesan iklan, lengkap dengan atribut yang merefleksikan bagaimana perjuangan pada masa lampau.

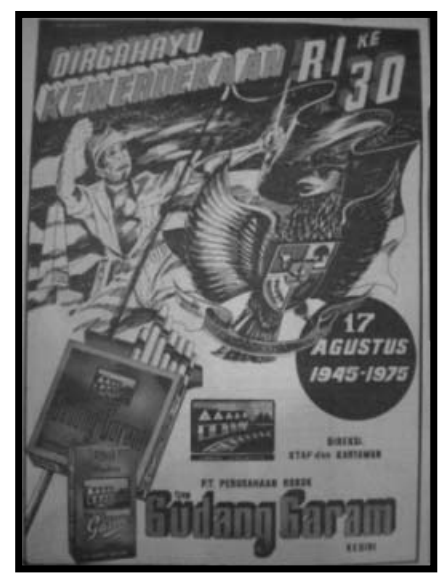

Iklan rokok "Gudang Garam"

Sumber: Kompas, Senin, 18 Agustus1975

Pasca kemerdekaan juga membawa dampak dalam penggunaan bahasa pada iklan. Menurut PPPI, periode periklanan modern Indonesia dalam kurun waktu 1967 hingga 1972 terjadi peralihan penggunaan bahasa asing sebagai bahasa pengantar naskah iklan dari bahasa Belanda menjadi bahasa Inggris. Pada periode itu penggunaan bahasa Inggris dalam iklan semakin tumbuh dan berkembang. Beberapa iklan yang diterbitkan pada masa postcolonial juga banyak yang mempergunakan istilah bahasa Inggris dalam iklannya. Kemampuan bahasa Inggris tampaknya mulai diperlukan bagi kebutuhan iklan yang semakin maju dengan pasar konsumen yang semakin heterogen.

\section{Elemen-elemen Keindonesian yang Dihadirkan}

Fenomena lain yang terjadi pada iklan rokok adalah elemen-elemen ke-Indonesian yang dihadirkan, dengan munculnya simbol- simbol pribumisasi dalam iklan, tak terkecuali pada iklan rokok. Iklan-iklan rokok dipenuhi dengan 'aktor-aktor' rakyat pribumi. Ini merupakan salah satu bentuk reaksi terhadap pengaruh penetrasi visualisasi barat (Budi Susanto, 2003: 47).

Penggunaan tokoh-tokoh pribumi, baik dalam penggambaran elite maupun masyarakat biasa pada ilustrasi iklan rokok, yang merupakan sebuah refleksi perkembangan zaman. Proses pribumisasi dalam desain masa itu dengan menampilkan simbol dan atribut ke-Islaman, kepriyayian, budaya Jawa, hingga bentuk representasi rakyat jelata yang dituangkan dalam visualisasi iklan rokok kala itu.

Iklan rokok hadir dengan ilustrasi yang merefleksikan kaum pribumi saat itu. Sosok priyayi tampil dengan atribut etnik lengkap seperti layaknya karakteristik masyarakat pribumi Jawa waktu itu, berpakaian Jawa lengkap dengan blangkon, kain batik dan baju lurik. Selain itu bentuk penghadiran figur rakyat kecil dan simbol-simbol kultural juga terdapat pada iklan rokok Faroka yang menghadirkan sosok/figur refleksi rakyat kecil dengan atribut tradisional seperti, beskap, destar, dan asesoris.

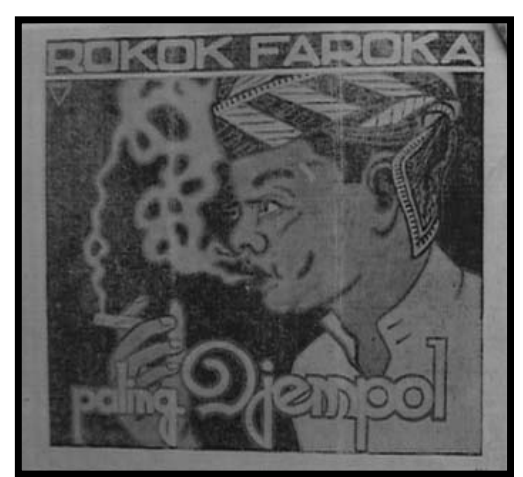

Iklan rokok "Faroka" Sumber: Sin Po, 7 April 1933
Tokoh-tokoh pewayangan juga menjadi daya tarik pasar oleh para perancang iklan zaman itu. Tokoh pewayangan dan cerita legenda dimanfaatkan sebagai merk dagang maupun sebagai ilustrasi dalam rancangan iklan rokok. 


\section{Simbol-simbol Modernisasi dalam Iklan Rokok pada 1930-1970an}

Perubahan besar teknologi cetak warna mempengaruhi perkembangan dunia iklan, khususnya iklan rokok. Sebenarnya pada akhir tahun 1950an bentuk tampilan iklan juga masih stagnan, namun sudah muncul iklan-iklan di media cetak yang memasang iklan dengan cetak warna, di mana sebelumnya hanya terdapat iklan hitam hitam putih saja (Hermanu, 2006: 19). Seperti pada tahun 1977, iklan rokok dengan cetak berwarna salah satunya adalah iklan rokok Commodore.

Bentuk simbol modernisasi dalam bidang teknologi lainnya adalah penggunaan foto dalam ilustrasi. Beralih dari penggunaan media gambar menjadi media foto membuat ilustrasi semakin beragam, menarik dengan kreativitas masing-masing. Foto yang digunakan sebagai ilustrasi biasanya dapat berupa foto-foto berwarna (tonal photographs) (Frank Jefkins, 1996: 247).

Pada tahun 1970an, terutama tahun 1977 ditandai dengan banyaknya dominasi iklaniklan rokok yang menggunakan ilustrasi foto. Tak dapat dipungkiri bahwa perubahan yang terjadi pada iklan, terutama iklan rokok saat itu akibat perkembangan teknologi percetakan dan teknologi pendukung yang semakin mutakhir, sumber daya manusia yang semakin terampil, industri rokok yang semakin berkembang, meningkatnya masyarakat konsumen, dan kondisi dalam negeri yang turut berperan dalam perkembangan iklan rokok di Indonesia.

Modernisasi dalam segala sisi, termasuk dalam tata cara berpakaian masyarakat yang tercermin dalam visualisasi iklaniklan rokok. Iklan rokok tahun 1930 hingga 1950an merefleksikan bentuk tata berpakaian masyarakat pada waktu itu dalam gambaran visual ilustrasinya. Tata berpakaian yang masih didominasi pakaian-pakaian tradisional sebagai simbol identitas pribumi seperti sarung, beskap, kebaya, kain batik panjang (jarik atau nyamping), dan kain lurik. Seperti terlihat pada iklan rokok HD. Mac Gillavry. Walaupun hingga kini masih digunakan namun bukan dalam fungsi utama pakaian keseharian, tetapi lebih sebagai simbol kultural.

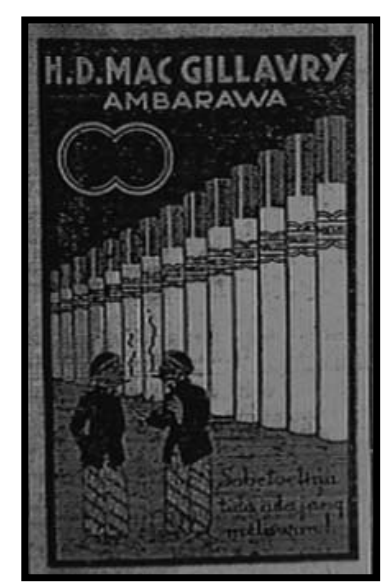

Iklan rokok "H.D. Mac Gillavry"

Sumber: Medan Doenia, 4 Januari 1930

Seiring dengan pengaruh mode dan arus perkembangan zaman yang kuat dan modernisasi, perubahan tampak jelas dalam gaya berpakaian masyarakat yang tercermin dalam visualisasi iklan rokok tahun 1960an dan 70an. Jas tak lagi hanya 'milik' orang Belanda atau golongan putih, tetapi secara universal telah digunakan oleh masyarakat Indonesia sebagai pakaian formal/resmi.

Gaya berpakain kosmopolitan terekam jelas dalam visualisasi iklan dengan penggambaran busana keseharian dan santai, seperti kemeja safari, celana panjang, kemeja perempuan, dan rok panjang untuk perempuan. Hal tersebut terekam dalam iklan rokok, yang juga terpengaruh dari unsur 'pembaratan' (Henk Schulte Nordhold, 2005: 27) dan dalam balutan desain yang modern. Gaya berpakaian tersebut merepresentasikan pakaian seharihari masyarakat tahun 1960an dan 1970an menggantikan kebaya, kain lurik atau beskap, dan kain jarik (batik) sebagai pakaian seharihari pribumi pada masa kolonial. 


\section{Model Perempuan dalam Iklan Rokok pada 1930-1970an}

Pranacitra ${ }^{5}$ adalah sedikit gambaran eksploitasi perempuan yang memberikan sedikit inspirasi mengenai pelibatan sosok perempuan dengan rokok pada masa itu. Roro Mendut, menarik perhatian para pria dalam menjual dagangan rokoknya dengan cara mempercantik diri sebagai daya pikat dan menghargai rokok dengan harga mahal, bahkan puntung rokok dihargai lebih mahal daripada rokoknya.

Roro jonggrang berusaha 'menjual' citranya yang dikenal cantik, lembut, dan sempurna untuk menarik daya perhatian kaum laki-laki. Stereotip yang berkembang dalam masyarakat, perempuan identik dengan kelembutan, keaggunan, keindahan, dan kelincahan. Namun siapa sangka perempuan memiliki andil dalam kaitannya dengan rokok yang notabene lebih identik dengan kaum laki-laki, bahkan terlibat langsung dalam sasaran pasarnya yang juga membidik pasar perempuan. Inilah yang tercermin dalam iklan-iklan rokok tahun 19301970an yang menggunakan sosok perempuan sebagai model secara eksplisit, yang tidak akan ditemui saat ini.

Makna yang terselip dalam kisah Pranacitra mungkin saja telah mengilhami para perancang iklan untuk menghadirkan figur perempuan dalam iklan rokok. Tahun 1930 hingga 1970an, iklan rokok tidak hanya didominasi oleh kaum pria, namun juga kaum perempuan. Figur perempuan turut menghiasi iklan rokok sebagai model atau bintang iklan kala itu. Tidak berlebihan jika kemudian citra perempuan dalam iklan rokok dimaknai oleh asumsi yang berbeda-beda.

Perempuan tak hanya digambarkan sebagai pemanis atau daya pikat semata, namun lebih jauh citra perempuan dalam iklan rokok juga berkaitan dengan segmen pasar yang dibidik, yakni kaum perempuan itu sendiri. Kaum perempuan juga menjadi target pasar konsumsi rokok.

Kenapa dipilih sosok perempuan sebagai model iklan rokok? Iklan terus berlomba untuk mencari inovasi penandanya, dengan tujuan esensial yakni pesan iklan dapat diterima secara efektif oleh masyarakat. Dalam sistem masyarakat yang masih didominasi ideologi patriarki ${ }^{6}$, maka hanya satu obyek penanda pada iklan yang mempunyai daya tarik lebih hebat selain sosok perempuan. Dari penanda inilah perempuan memberikan rangsangan, rayuan, godaan, dan sekaligus sebagai bentuk ekspolitasi (Kasiyan, 2008: vii).

Dua makna fundamental yang dapat diidentifkasi terkait citra figur perempuan dalam iklan-iklan rokok di atas, pertama, bahwa perempuan memang ditampilkan sebagai sosok pemanis atau dekoratif yang tuntutannya jelas, perempuan ditampilkan dalam rangka sebagai penarik dan daya pikat konsumen yang sebagian besar adalah kaum laki-laki. Kedua, bahwa iklan rokok tersebut memang ditujukan juga untuk kaum perempuan.

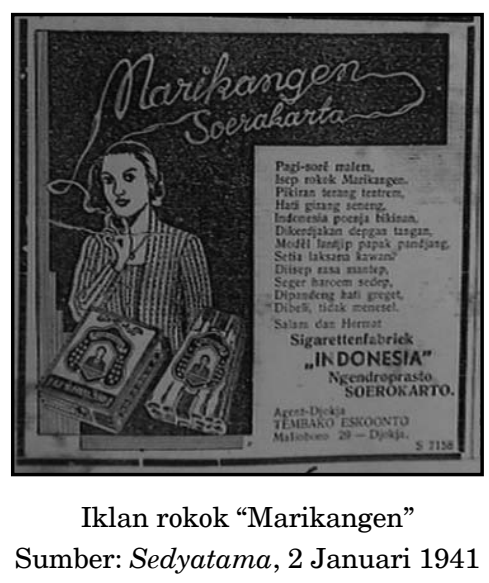

\section{Kesimpulan}

Berdasarkan penelitian yang telah dilakukan pada iklan rokok kurun waktu antara tahun 1930 hingga 1970an telah terjadi transformasi dalam 'wajah' desain iklan rokok yang fundamental, yaitu, pada penggunaan foto sebagai media ilustrasi iklan rokok dan 
munculnya iklan rokok dengan cetak berwarna. Hal itu dianggap sebagai sebuah kemajuan dalam bidang teknologi.

Perkembangan kreativitas desain iklan rokok secara garis besar dapat dibagi menjadi tiga periode utama, yaitu Periode I (19301950an), Periode II (1960an), dan Periode III (1970an). Iklan rokok tahun 1930 hingga 1950an diklasifikasikan dalam satu periode, hal ini didasarkan atas adanya banyak kesamaan, keseragaman ciri yang dihadirkan iklan rokok pada kurun 1930 hingga 1950an.

Iklan rokok juga telah merefleksikan simbol-simbol modernisasi yang terekam dalam jejak visualisasi iklan-iklan rokok tahun 1930 hingga 1970an antara lain modernisasi dalam bidang teknologi (foto dan iklan cetak warna) dan tercermin dalam mode atau fashion masyarakat pada waktu itu.

Tak dapat dipungkiri bahwa perkembangan dan transformasi pada iklan rokok telah memberikan gagasan mengenai kreativitas yang semakin beragam dan menjadi refleksi, alat bukti yang merekam gambaran perubahan rezim politik dan modernisasi di Indonesia pada tahun 1930 hingga 1970an.

\section{Daftar Pustaka}

\section{Surat Kabar}

Medan Doenia, 4 Januari 1930

Sin Po, 7 April 1933

Sin Po, 6 Mei 1933

Sin Po, 24 Juni 1933

Sin Tit Po, 26 Januari 1937

Sin Po, 29 Januari 1937

Sedyatama, 2 Januari 1941

Bintang Timoer, 7 April 1959

Kompas, 18 Agustus 1975

Kompas, 2 Mei 1977

\section{Buku}

Budiman Hakim. Lanturan Tapi Relevan, Yogyakarta: Galangpress, 2005.

Bedjo Riyanto. Iklan Surat Kabar dan Perubahan Masyarakat di Jawa 1870-1915, Yogyakarta: Tarawang, 2000.

Marwati Djoened Poesponegoro. Sejarah Nasional Indonesia VI, Jakarta: Balai pustaka, 1992.

PPPI. Reka Reklame: Sejarah Periklanan Indonesia 1844-1984. Jakarta: PPPI, 1993.

Budi Susanto. Identitas dan Postkolonialitas di Indonesia. Yogyakarta: Penerbit Kanisius, 2003.

Frank Jefkins. Periklanan. Jakarta: Erlangga, 1996.

Kasiyan. Manipulasi dan Dehumanisasi Perempuan dalam Iklan. Yogyakarta: Penerbit Ombak, 2008.

Emmanuel Subangun, et al. Industri Hasil Tembakau. Jakarta: Satuan Tugas Industri Rokok, 1993.

Amen Budiman, et al., Rokok Kretek Lintas Sejarah dan Artinya bagi Pembangunan Bangsa dan Negara. Kudus: PT.Djarum, 1987.

Hermanu. PIKAT, Pameran Iklan Cetak Generasi II. Yogyakarta: Bentara Budaya, 2006.

Nordholt, Henk Schulte (ed.). Outward Appearances: Trend, Identitas, Kepentingan. Yogyakarta LKIS: 2005.

B. Wahyudi Joko Santoso. 'Iklan Rokok: Kajian Struktural dan Pragmatik', Tesis S-2 Universitas Gadjah Mada, 2000.

\section{Catatan Akhir}

1. AKROBAT adalah Alkohol, Kondom, Rokok, dan Obat-obatan.

2. Siluet adalah efek yang dihasilkan dalam gambar/fotografi karena adanya perbedaan signifikan antara pantulan cahaya objek utama di bagian depan gambar dengan latar belakangnya. 
3. Kata-kata sederhana serta biasa digunakan dan kadang tampak unik yang terbukti sangat sukses diaplikasikan pada periklanan

4. Iklan testimonial merupakan gaya mengemukakan pendapat, pernyataan, dan pujian dari seorang atau beberapa orang tokoh masyarakat (public figure) terhadap kehebatan produk yang diiklankan.

5. Pranacitra adalah sebuah kisah percintaan segitiga yang terjadi pada masa kekuasaan kerajaan Mataram antara Roro mendut, Tumneggung Wiraguna, dan Pranacitra.

6. Patriarkhi merupakan suatu sistem kemasyarakatan yang dalam ketatakeluargaan menempatkan ayah atau pihak laki-laki sebagai garis keturunan, jadi seorang anak harus menyandang nama ayahnya dan pewarisan harta pusaka diturunkan dari pihak ayah (pada anak laki-laki). 
